\title{
Regulation, Market Structure, Risk and Bank Profitability in the Emerging Countries during the Subprime Crisis
}

\author{
BEN MBAREK Hassene, ${ }^{1, *}$, BEN MBAREK Kais ${ }^{2}$, KHEMIRI Souad ${ }^{3}$ \\ ${ }^{1}$ Head of Finance and Accountability Department at the Higher School of Economic and Commercial Sciences of Tunis and Member \\ of CEDAG Research Unit at Paris 5 Descartes, France \\ ${ }^{2}$ INSI, informatics institute, university of Manouba, Tunisia \\ ${ }^{3}$ Responsible of International Cooperation at the University of Tunis and Member of the Interdisciplinary Research on Economies and \\ Business Changes Laboratory (LARIME) at the Higher School of Economic and Commercial Sciences of Tunis \\ *Corresponding author: hassene_mbarek@yahoo.fr
}

Received January 02, 2015; Revised January 16, 2015; Accepted February 25, 2015

\begin{abstract}
The aim of this paper is to study the effect of the regulatory and institutional environment on banking behavior using a panel of conventional banks in 10 emerging countries over the period 2007-2012. To this end, we adopt a simultaneous equations model to capture the dynamic adjustments of banking behavior and efficiency. The results indicate that there is a negative and significant impact of institutional quality on equity and risk. However, we find a positive and significant impact of the institutional environment on banking efficiency indicating the effectiveness of equity regulation insofar as it helped to increase the strength and stability of the international banking system. The imposition of regulatory requirements reduces credit risk and highlights the importance of market discipline as a crucial element in implementing effective regulation and supervision strategies.
\end{abstract}

Keywords: banking behavior, efficiency, banking regulation, regulatory and institutional environment

Cite This Article: BEN MBAREK Hassene, BEN MBAREK Kais, and KHEMIRI Souad, "Regulation, Market Structure, Risk and Bank Profitability in the Emerging Countries during the Subprime Crisis." Journal of Finance and Economics, vol. 3, no. 1 (2015): 15-19. doi: 10.12691/jfe-3-1-3.

\section{Introduction}

During the last decade, the frequency and size of financial crises have continued to grow and increase throwing a large number of countries in severe banking crisis. This phenomenon has induced economists to look for solutions to the stability of the financial system. The institutional environment is an important element in the banking structure of emerging countries. Indeed, an inadequate banking supervision device could lead banks to take excessive risk. Moreover, a well-stable environment could lead to equity flight because of rapid loss of confidence .Lack of a well-structured institutions in an economy leads to a less efficient banking behavior that accumulates bad debts and produces less winning margins. Theoretically, work on the optimal structure of equity regulation and its impact on banking risk taking resulted in contradictory results [Santos (2000), Rochet (2008)]. The main purpose of this study is to evaluate banks' performance and efficiency of some emerging countries and analyze their responses to the institutional environment in terms of changes in equity, portfolio risk management and their effectiveness. Furthermore, we try to test the presence of a relationship between equity, risk and efficiency in the banking system.
In this study, we estimate a simultaneous equations model developed by Shrieves and Dahl (1992) following the work of Youssef D. (2009) to present the impact of regulation, on the one hand, on bank risk and performance and, on the other hand, on the relationship between equity, risk and bank profitability in emerging countries.

Our paper is organized as follows: In the first section we present a review of literature on the relationship between institutional environment and banking behavior and efficiency. In the second section we present the empirical specification, the model and the methodology. The results are shown in the third section. The fourth section concludes the paper.

\section{Review of the Literature on Institutional Environment, Banking Behavior and Efficiency}

In their study on the impact of bank regulation and the environment on banks' net interest margins, DemerguçKunt et al. (2004) found that there is a significant empirical link between institutional environment and banking efficiency. In another study using the stochastic frontier approach to define banking efficiency, Pasiouras 
et al. (2007) confirmed the results obtained by DemerguçKunt et al. (2004).

According to Barth et al. (2006), an inefficient regulation and supervision banking system greatly increases incentives for excessive risk taking. Lack of regulators' response pushes banks to freely engage in excessive risky activities. Market discipline plays an important role in implementing regulation and supervision strategies. Insufficient discipline makes less conservative leaders in the field of risk-taking that may affect banks control.

Laporta et al. (2000) show that in an unstable institutional and regulatory environment, banks and investors are in critical situations. The former are no longer protected against the non-payment of their funds and are unable to recover their dues. Investors become suspicious, lose confidence and withdraw their equity.

Banks inability to build by themselves depositors trust led to the intervention of exogenous institutions into the banking system as the last-resort lender that can slow withdrawals movement to prevent bankruptcies and limit losses of insolvent institutions. However, the central bank intervention as a last resort to restore bank liquidity can generate a moral hazard. Moral hazard occurs when the lending policy leads to a relaxation of market discipline and encourages banks to take excessive risks and to be less cautious in managing their liquidity positions. This led public authorities to implement prudential regulation to cancel moral hazard. One way to reduce insolvency probability and mitigate moral hazard induced by implicit deposit insurance is to make bankruptcy more costly for the bank's shareholders by limiting leverage and increasing equity requirements. Such a measure is supposed to encourage banks to be more prudent in managing their risks and limit insurance funds intervention.

\subsection{Interdependence between Efficiency, Equity and Risk}

According to Hughes and Mester (1998) equity and risk are influenced by bank efficiency level. Managers who are less effective in evaluating and monitoring bank loans will not be very effective in terms of operational efficiency.

A bank may choose to maximize short-term profits by reducing equity for the allocation and monitoring of bank loans. This will raise risk measures and efficiency, creating a positive relationship between efficiency and short-term risk. The empirical literature focusing on the determinants of bank risk assumes that equity and risk are simultaneously determined [Aggarwal and Jacques (2001)]. Banks at high risk may choose higher interest margins. However unprofitable banks are tempted to grant more random credits and engage in more uncertain activities to defend their profitability and comply with prudential regulations imposed by monetary authorities.

\subsubsection{The Basic Model and the Empirical Specification}

Analysis of bank equity behavior and risk level is done through a simultaneous equations model developed by Shrieves and Dhal (1992). This model assesses the impact of bank regulation on changes in equity and bank risk level. In this model, the author evaluates how banks respond to requirements imposed by regulatory authorities.
An important aspect of the model is that changes in equity and risk have two components, one endogenous and the other a random shock determined exogenously:

$$
\begin{gathered}
\Delta C A P_{i j, t}=\Delta^{d} C A P_{i j, t}+u_{i j, t} \\
\Delta R I S K_{i j, t}=\Delta^{d} R I S K_{i j, t}+v_{i j, t}
\end{gathered}
$$

With $\triangle C A P_{i j, t}$ and $R I S K_{i j, t}$ are the observed changes in equity and the risk levels of bank $\mathrm{i}$ in country $\mathrm{j}$.

$\Delta^{d} C A P_{i j, t}$ and $\Delta^{d} R I S K_{i j, t}$ represent endogenous adjustments to equity and risk of bank $\mathrm{i}$ in country j during period t. $u_{i j, t}$ and $v_{i j, t}$ are error terms.

Endogenous adjustments of equity and risk are formulated according to a partial adjustment. In this context, endogenous changes in equity and risk are proportional to the difference between the desired levels and observed levels at time t-1 CAP $P_{i j, t-1}$ and $R I S K_{i j, t-1}$

$$
\begin{gathered}
\Delta^{d} C A P_{i j, t}=\alpha\left(C A P_{i j, t}^{*}-C A P_{i j, t-1}\right) \\
\Delta^{d} R I S K_{i j, t}=\beta\left(R I S K_{i j, t}^{*}-R I S K_{i j, t-1}\right)
\end{gathered}
$$

With $C A P_{i j, t}^{*}$ and $R I S K_{i j, t}^{*}$ represent the desired equity and risk of bank $\mathrm{i}$ located in country $\mathrm{j}$ at time $\mathrm{t}$. Substituting equations (3) and (4) into (1) and (2) we obtain:

$$
\begin{gathered}
\Delta \operatorname{CAP}_{i j, t}=\alpha\left(\operatorname{CAP}_{i j, t}^{*}-C_{i j, t-1}\right)+u_{i j, t} \\
\Delta R I S K_{i j, t-1}=\beta\left(\operatorname{RISK}_{i j, t}^{*}-R I S K_{i j, t-1}\right)+v_{i j, t}
\end{gathered}
$$

The desired equity and risk levels are not directly observable but are assumed to be dependent on a group of observable variables describing the bank's financial condition of and the economy state in each country.

In this study, individual variables are taken from Bankscope Software. The data relate to the details of assets and liabilities as well as income statements. These data are annual and expressed in thousands of U.S. dollars. Similarly, banks that do not have at least two annual observations of their equity were removed from the database. We also integrated institutional and regulatory variables using the database of Barth et al. (2001). The sample includes 139 banks across 10 emerging countries over the period 2007 to 2012.

Table 1. The sample

\begin{tabular}{|c|c|}
\hline \multicolumn{2}{|c|}{ Table 1. The sample } \\
\hline Countries & Total number of banks \\
\hline Tunisia & 13 \\
\hline Mexico & 22 \\
\hline Jordan & 9 \\
\hline Lebanon & 20 \\
\hline Saudi Arabia & 7 \\
\hline Morocco & 7 \\
\hline Philippine & 10 \\
\hline Thailand & 11 \\
\hline Indonesia & 20 \\
\hline Malaysia & 20 \\
\hline
\end{tabular}

We extend the basic model by including a third equation modeling banking efficiency. We assume that the variables equity, risk and bank efficiency are interdependent. Each specified variable affects the other two and at the same time it is explained by the other two. Banking efficiency is represented as follows: 


$$
\Delta E F F_{i j, t}=\gamma\left(E F F_{i j, t}^{*}-E F F_{i j, t-1}\right)+\omega_{i j, t}
$$

Equations (5), (6) and (7) assume that changes in equity, risk and efficiency depend on the desired equity, risk and efficiency of lagged values of these variables and all exogenous factors. Independent variables and their expected impact on banking behavior and efficiency were used by Shrieves and Dahl (1992), Rime (2001).

The model to be estimated can be written as follows for bank $\mathrm{i}$ in country $\mathrm{j}$ at time t:

$$
\begin{aligned}
& \Delta C A P_{i j, t}=\alpha_{0}+\alpha_{1} S I Z E_{i j ' t}+\alpha_{2} \Delta R I S K_{i j, t}+\alpha_{3} L I Q_{i j, t} \\
& +\alpha_{4} C A P_{i j, t-1}+\alpha_{5} \Delta E F F_{i j, t}+\alpha_{6} R E G_{i j, t}+u_{i j, t} \\
& \triangle R I P K_{i j, t}=\beta_{0}+\beta_{1} S I Z E_{i j ' t}+\beta_{2} \Delta C A P_{i j, t} \\
& +\beta_{3} L I Q_{i j, t}+\beta_{4} P_{R O V_{i j, t}}+\beta_{5} R_{I S K} K_{i j, t-1} \\
& +\beta_{6} \Delta E F F_{i j, t}+\beta_{7} R E G_{i j, t}+v_{i j, t} \\
& \Delta E F F_{i j, t}=\gamma_{0}+\gamma_{1} S I Z E_{i j ' t}+\gamma_{2} \Delta C A P_{i j, t}+\gamma_{3} R I S K_{i j, t} \\
& +\gamma_{4} L I Q_{i j, t}+\gamma_{5} E F F_{i j, t-1}+\gamma_{6} R E G_{i j, t}+\vartheta_{i j, t}
\end{aligned}
$$

\subsubsection{Overview of Variables}

Using this estimation method is motivated by the fact that there is interdependence between the endogenous variables. Therefore, this method provides robust parameters estimates. Increase in equity can raise equity cost and credit institution would have to set a higher interest margin. Moreover, increase in equity can positively affect interest margin through an increase in weighted average equity cost and an increase in risk induced by portfolio expansion to riskier and more profitable assets.

\subsubsection{Endogenous Variables}

$$
\begin{aligned}
C A P_{i j, t} & =\frac{\text { Equity }}{\text { totalaassets of ababiin country jattimet }} \\
R I S K_{i j, t} & =\frac{\text { bad debts }}{\text { totalassents }} \\
E F F_{i j, t} & =\frac{\text { net int erest income }}{\text { average producative assets }}
\end{aligned}
$$

\subsubsection{Exogenous Variables}

$$
\begin{aligned}
S I Z E_{i j^{\prime} t}= & \text { logarithm of total assets for banks } \mathrm{i} \\
& \text { in country } \mathrm{j} \text { at time } \mathrm{t} .
\end{aligned}
$$

This variable is considered as a control variable because it can affect equity, risk and bank profitability through economies of scale. Large banks can easily have access equity markets and diversify their portfolios. They are supposed to hold a level of equity and lower risk than smaller banks.

$$
L I Q_{i j, t}=\frac{\text { Liquid assets }}{\text { customer deposits }}
$$

Banks have sufficient liquidity and can easily raise the necessary funds to meet deposit withdrawals or demand for new credit can be more profitable and require less equity than other banks.

$$
P R O V_{i j, t}=\frac{\text { depreciation } \text { ch } \arg \text { es }}{\text { totalassets }}
$$

This ratio is introduced into the equation explaining credit risk because it lowers risk level. Therefore, the sign of the expected $\beta \_4$ coefficient is negative.

$$
\begin{aligned}
& \operatorname{CAP}_{i j, t-1}=\frac{\text { Equity }}{\text { totalaassets of ababiin country jattimet }-1} \\
& R I S K_{i j, t}=\frac{\text { bad debts }}{\text { totalassentsattimet }-1} \\
& E F F_{i j, t}=\frac{\text { net int } \text { erest income }}{\text { average producative assetsattimet }-1}
\end{aligned}
$$

We also introduced next to these variables, three proxies for the regulatory environment in order to study their impact on equity, risk and profitability, presented as follows:

1. Insurance Deposit: the extent to which regulators allow banks to conduct insurance and investment activities. Lower values ndicate the presence of a small number of restrictions.

2. Regulation of equity: this variable included in the model is built from five indicators related to banking regulation and supervision for which the data were collected by Barth et al. (2006) and used in our model. These indicators are as follows:

- Entry of new banks in the market.

- Regulatory capital index

- Degree of restrictions on banking

- Private banking supervision index

\begin{tabular}{|c|c|c|c|}
\hline VARIABLE & $\triangle C A P$ & $\Delta R I S K$ & $\Delta E F F$ \\
\hline Size & $\begin{array}{c}-0,028 * * * \\
(-4,13)\end{array}$ & $\begin{array}{c}-0,008 * * * \\
(-2,58)\end{array}$ & $\begin{array}{c}-0,0056^{* *} \\
(-2,038)\end{array}$ \\
\hline$\triangle C A P$ & - & $\begin{array}{c}-0,335 * * * \\
(-2,67)\end{array}$ & $\begin{array}{c}0,103^{* * *} \\
(5,66)\end{array}$ \\
\hline$\Delta R I S K$ & $\begin{array}{c}-0,038 * * * \\
(-0,07)\end{array}$ & - & $\begin{array}{c}0,035 \\
(0,987)\end{array}$ \\
\hline$\triangle E F F$ & $\begin{array}{c}0,988^{* * *} \\
(0,35)\end{array}$ & $\begin{array}{c}1,054 * * * \\
(0,67)\end{array}$ & - \\
\hline LIQ & $\begin{array}{l}0,55 * * * \\
(3,354)\end{array}$ & $\begin{array}{c}0,024 \\
(1,531)\end{array}$ & $\begin{array}{l}-0,006 \\
(-1,33)\end{array}$ \\
\hline PROV & - & $\begin{array}{c}1,354 * * * \\
(6,86)\end{array}$ & - \\
\hline$C A P(t-1)$ & $\begin{array}{c}-0,268 * * * \\
(-9,21)\end{array}$ & - & - \\
\hline RISK (t-1) & - & $\begin{array}{c}-2,321 * * * \\
(-4,38)\end{array}$ & - \\
\hline$E F F(t-1)$ & - & - & $\begin{array}{c}-0,374 * * * \\
(-1,22)\end{array}$ \\
\hline $\begin{array}{c}\text { Observations } \\
\mathbf{R}^{2}\end{array}$ & $\begin{array}{c}695 \\
0,264 \\
\end{array}$ & $\begin{array}{c}695 \\
0,432 \\
\end{array}$ & $\begin{array}{c}695 \\
0,157\end{array}$ \\
\hline
\end{tabular}

- Banking supervision power.

It should be noted that banks with low equity might be tempted to take on more risk because they hope that higher yields will increase their equity. We expect a positive effect of regulatory pressure on equity.

3. Supervision: This is an index measuring the extent of the supervisory authorities power to take specific actions to prevent problems. It also comes from the database used by Barth et al. (2006).

\subsubsection{Interpretation of Results}

Estimation of the model was performed according to the least squares method. Table 2 below shows the results of the regression taking into account the effects countries and years.

Table 2. Regression taking into account the effects countries and years 
The results show that the bank size (SIZE) has a negative impact on changes in equity. This result indicates that increasingly larger banks in emerging countries have easier access to equity markets and can be operational with a lower level of equity and thus operate with smaller amounts of equity. The negative and significant impact of bank size on risk change implies that large banks engage in important activities that should increase their ability to diversify their portfolios and thus to reduce their credit risk.

The $L I Q_{i j, t}$ ratio is positively related to changes in equity and risk levels, suggesting that the most liquid banks hold higher equity and risk levels. Banks in emerging countries prefer to increase their equity by using their retained earnings. Depreciation and provisions have a positive effect on change in risk, which means that in emerging countries, level of reserves does not discourage banks to take advantage of risk.

CAP (-1), RISK (-1)and EFF (-1) variables have a negative and significant impact on respectively equity, risk and net interest margin, indicating that banks in emerging countries have poorly adjusted their equity, risk and the interest margin ratios during the study period. In emerging banking system, improving institutions leads to a weaker equity requirements. Despite the efforts put in place, institutions of these countries are improving very slowly, hence the need for a rigorous banking regulation that explains why equity adequacy ratios of banks are quite high. In the case of improved institutions, it is therefore expected to lower excessive risk-taking by the banking sector. Table 2 also shows the existence of a positive and significant relationship between change in equity and in net interest margin, indicating that the most profitable banks tend to increase their level of equity but also an increase inequity may lead the bank to set a higher interest margin. Similarly, there is a positive and significant relationship between change in risk and net interest margin, which suggests that banks exposed to a high risk choose higher interest margins which is the case of most banks in Tunisia because of the democratic transition crisis.

Table 3 below presents the results of the estimation taking into account the effect of banking activities regulation on bank decisions on equity, risk and net margin interest. It follows then, restrictions on banking activities are negatively related to equity and risk and have a positive effect on interest margin. This is explained by the fact that when banks are allowed to drive a wide variety of financial activities and do not separate between commercial and investment activities, they take excessive risks. Regulation of banking activity therefore appears effective in emerging countries, with higher restrictions on activities, risk is reduced and interest margin is high.

Table 4 shows the effect of the presence of an insurance deposit system on equity, risk and interest margin, which shows the existence of a negative impact on changes in equity and risk and a positive impact on net interest margin. The existence of an insurance deposit system seems to negatively influence equity development because it reduces the incentive for banks to report a good performance, but reduces excess risk and improves bank profitability. However, in emerging countries, the existence of a guarantee fund protects depositors reduces excess risk of the bank that should not generate significant revenues and report a strong performance to its customers and avoid liquidity problems.

Table 3. Results of the estimation taking into account the effect of banking activities regulation

\begin{tabular}{|c|c|c|c|}
\hline VARIABLE & $\triangle C A P$ & $\Delta R I S K$ & $\triangle E F F$ \\
\hline SIZE & $\begin{array}{c}-0,436^{* * *} \\
(-4,123)\end{array}$ & $\begin{array}{c}-0,047 * * * \\
(-0,228)\end{array}$ & $\begin{array}{c}-0,049 * * * \\
(-2,33)\end{array}$ \\
\hline$\triangle C A P$ & - & $\begin{array}{c}-0,245^{* * *} \\
(-2,85)\end{array}$ & $\begin{array}{c}0,155^{* * *} \\
(5,789)\end{array}$ \\
\hline$\Delta R I S K$ & $\begin{array}{l}-0,039 \\
(-0,14)\end{array}$ & - & $\begin{array}{l}0,036 \\
(1,33)\end{array}$ \\
\hline$\triangle E F F$ & $\begin{array}{c}0,087 \\
(0,234)\end{array}$ & $\begin{array}{l}-0,542 \\
(-1,98)\end{array}$ & - \\
\hline LIQ & $\begin{array}{c}0,043^{* * *} \\
(3,224)\end{array}$ & $\begin{array}{c}0,043^{* * *} \\
(2,765)\end{array}$ & $\begin{array}{c}-0,056 \\
(-1,776)\end{array}$ \\
\hline PROV & - & $\begin{array}{c}1,754 * * * \\
(6,56)\end{array}$ & - \\
\hline$C A P(t-1)$ & $\begin{array}{c}-0,288 * * * \\
(-7,654)\end{array}$ & - & - \\
\hline RISK (t-1) & - & $\begin{array}{c}-0,233 * * * \\
(-11,94)\end{array}$ & - \\
\hline$E F F(t-1)$ & - & - & $\begin{array}{c}-0,198 * * * \\
(-8,22)\end{array}$ \\
\hline$R E G$ & $\begin{array}{c}0,332 * * * \\
(1,55)\end{array}$ & $\begin{array}{c}-0,144 * * * \\
(-3,324)\end{array}$ & $\begin{array}{c}-0,0068 * * * \\
(-2,731)\end{array}$ \\
\hline Constante & $\begin{array}{c}0,156 * * * \\
(4,453)\end{array}$ & $\begin{array}{c}0,113 * * * \\
(3,137)\end{array}$ & $\begin{array}{c}0,023^{* * *} \\
(1,119)\end{array}$ \\
\hline Observations & 695 & 695 & 695 \\
\hline $\mathbf{R}^{2}$ & 0,278 & 0,233 & 0,143 \\
\hline
\end{tabular}

Table 4. Results of the estimation with insurance deposit system on equity

\begin{tabular}{|c|c|c|c|}
\hline VARIABLE & $\triangle$ CAP & $\Delta$ RISK & $\Delta \mathrm{EFF}$ \\
\hline SIZE & $\begin{array}{c}-0,342 * * * \\
(-4,322)\end{array}$ & $\begin{array}{c}-0,075 * * * \\
(-2,456)\end{array}$ & $\begin{array}{c}-0,341 * * * \\
(-1,17)\end{array}$ \\
\hline$\triangle C A P$ & - & $\begin{array}{c}-0,22 * * * \\
(-3,477)\end{array}$ & $\begin{array}{c}0,113^{* * *} \\
(5,988)\end{array}$ \\
\hline ARISK & $\begin{array}{c}0,043 \\
(7,887)\end{array}$ & - & $\begin{array}{c}0,036 \\
(0,177)\end{array}$ \\
\hline$\triangle E F F$ & $\begin{array}{c}0,533 \\
(1,503)\end{array}$ & $\begin{array}{c}-0,869 \\
(-0,891)\end{array}$ & - \\
\hline LIQ & $\begin{array}{c}0,0227 * * * \\
(2,897)\end{array}$ & $\begin{array}{c}0,076 * * * \\
(2,784)\end{array}$ & $\begin{array}{c}-0,036 \\
(-1,754)\end{array}$ \\
\hline PROV & - & $\begin{array}{c}1,773 * * * \\
(6,967)\end{array}$ & - \\
\hline$C A P(t-1)$ & $\begin{array}{c}-0,342 * * * \\
(-7,931)\end{array}$ & - & - \\
\hline $\operatorname{RISK}(t-1)$ & - & $\begin{array}{c}-0,348 * * * \\
(-12,57)\end{array}$ & - \\
\hline $\operatorname{EFF}(t-1)$ & $\begin{array}{l}- \\
-\end{array}$ & - & $\begin{array}{c}-0,289 * * * \\
(-7,677)\end{array}$ \\
\hline $\begin{array}{c}\text { Insurance } \\
\text { deposit }\end{array}$ & $\begin{array}{c}-1,665 * * * \\
(-3,972)\end{array}$ & $\begin{array}{c}-0,754 * * * \\
(-4,633)\end{array}$ & $\begin{array}{c}-1,003 * * * \\
(-3,243)\end{array}$ \\
\hline Constante & $\begin{array}{c}0,144 * * * \\
(3,554)\end{array}$ & $\begin{array}{c}0,049 * * * \\
(2,532)\end{array}$ & $\begin{array}{c}0,006 * * * \\
(2,812)\end{array}$ \\
\hline Observations & 695 & 695 & 695 \\
\hline$R^{2}$ & 0,278 & 0,176 & 0,143 \\
\hline
\end{tabular}

Similarly, it should be noted that in developing countries the existence of a strict and rigorous supervision system is supposed to constrain banks' risk-taking behavior. Regulations on the control of banks by the private sector, i.e. those that require banks to approve external auditors and international rating agencies, which in turn require banks to take more stringent measures, are assumed to reduce risk and improve bank performance. However, in emerging economies it should be noted that information in the banks may be incomplete; risk management procedures may be inadequate and therefore have no effect on market discipline. Moreover market participants do not have the knowledge and skills needed to use available information. 


\section{Conclusion}

This paper examined banking behavior and efficiency in terms of equity, risk and net interest margin taking into account the regulatory and institutional environment in some emerging countries over the period 2007-2012. To this effect, we used a simultaneous equations model like in the work of Shrieves and Dahl (1992).

The results indicate that improving the institutional environment in a country reduces equity requirement of a bank and its exposure to credit risk. Moreover, banking efficiency increases in a more efficient institutional environment. It should also be noted that the effect of bank regulation on banking behavior and efficiency is completely absorbed by the institutional environment. Inefficient banks in emerging countries that are still below the $8 \%$ threshold in terms of equity adequacy ratio are very sensitive to regulatory pressure. Prudential regulatory policies pursued by monetary authorities in emerging countries have been effective in increasing equity adequacy ratios.

\section{References}

[1] Aggarwal Raj and Kevin Jacques (2001): «Assessing the impact of prompt corrective action on bank capital and risk» Journal of Banking and Finance 25(6): 1139-1160, June.
[2] Barth James, Caprio Gerard and Levine Ross (2006): «Rethinking Bank Regulation: Till Angels Govern» Cambridge university press, p.428.

[3] Demirguc-KuntAsli, Laeven Luc and Levine Ross (2004): «Regulation, market structure, institutions and the cost of financial intermediation» Journal of Money, Credit and Banking, 36(3): 593-621.

[4] Hughes Joseph and MesterLoretta (1998): «Bank capitalization and cost: evidence of scale economies in risk management and signaling», Review of Economics and Statistics, 80(2)/ 314-325.

[5] Laporta Rafael, Lopez-de-Silanes Florencio, Shleifer Andrei and Vishny Robert (2000): «Investor protection and corporate governance», Journal of Financial Economics, 58(1-2): 3-27.

[6] Pasiouras Fotios, GaganisChrysovalantis and ZopounidisConstantin (2007): «The impact of bank regulation, supervision, market structure and bank characteristics on individual bank rating: a cross country analysis», Review of Quantitative Finance and Accounting, 27(4) : 403-438.

[7] Rime Bertrand (2001): «Capital requirements and bank behavior: empirical evidence for Switzerland», Journal of Banking and Finance, 25(4): 789-805.

[8] RochetJean-Charles (2008): «Why are there so many banking crises? The politics and policy of bank regulation», Princeton University Press.

[9] Santos João (2000): «Bank capital regulation in contemporary banking theory: a review of the literature», Bank for International Settlements, Working paper $\mathrm{n}^{\circ} 90$.

[10] Shrieves Ronaldand Dahl Drew (1992): « The relationship between risk and capital in commercial banks», Journal of Banking and Finance, $n^{\circ} 16$.

[11] Youssef Darine (2009): «L'impact de l'environnement institutionnel et de la régulation bancaire sur le comportement et l'efficacité bancaire: le cas de la région du MENA», Rapport technique, Université Paris 13. 